Christmas Music from Baroque Mexico 



\section{Christmas Music from Baroque Mexico}

By

ROBERT STEVENSON

\section{UNIVERSITY OF CALIFORNIA PRESS}

Berkeley Los Angeles London 
University of California Press

Berkeley and Los Angeles, California

University of California Press, Ltd.

London, England

Copyright (C) 1974 by

The Regents of the University of California

ISBN: 0-520-02036-7

Library of Congress Catalog Card Number: 70-157826

Printed in the United States of America 
A. M. D. G.

Escuchenme los valientes esta verdadera

historia que al fin se canta la

gloria y a El la cantan al nacer

(lines from a 1653 jacara set by Juan Gutierrez de Padilla for Christ-

mas performance in Puebla Cathedral
La mejor voz del mundo pierde de sus quilates quando no se acompaña con

el instrumento, ora sea de guitarra o clauizimbano, de organos o de harpa (Cervantes Saavedra, El Zeloso estremefio [1613]) 
